Melnyk Oksana \& Teneshev Vyacheslav (2019) Problemni pytannya pravovoho rehulyuvannya diyal'nosti sub"yektiv, yaki zdiysnyuyut' okhoronu ta zakhyst viys'kovoho mayna [Problematic issues of legal regulation of the activities of entities engaged in the protection and defense of military property]. Social development \& Security. 9(4), 61 - 73. DOI: http://doi.org/10.33445/sds.2019.9.4.4

\title{
Проблемні питання правового регулювання діяльності суб'єктів, які здійснюють охорону та захист військового майна
}

\author{
Оксана Мельник *, Вячеслав Тснсшев ** \\ * Військовий інститут Київського національного університету імені Тараса Шевченка, \\ вул. Ломоносова, 81, м. Київ, 03022, Украӥна, \\ e-mail:o_mel_nik@ukr.net, \\ ад'юнкт науково-організаційного відділення. \\ ** Тернопільський національний економічний університет, \\ вул. Львівська, 11 м. Тернопіль 46009, Україна, \\ e-mail: krakatuk14@gmail.com, \\ викладач кафедри міжнародного права, міжнародних відносин і дипломатії.
}

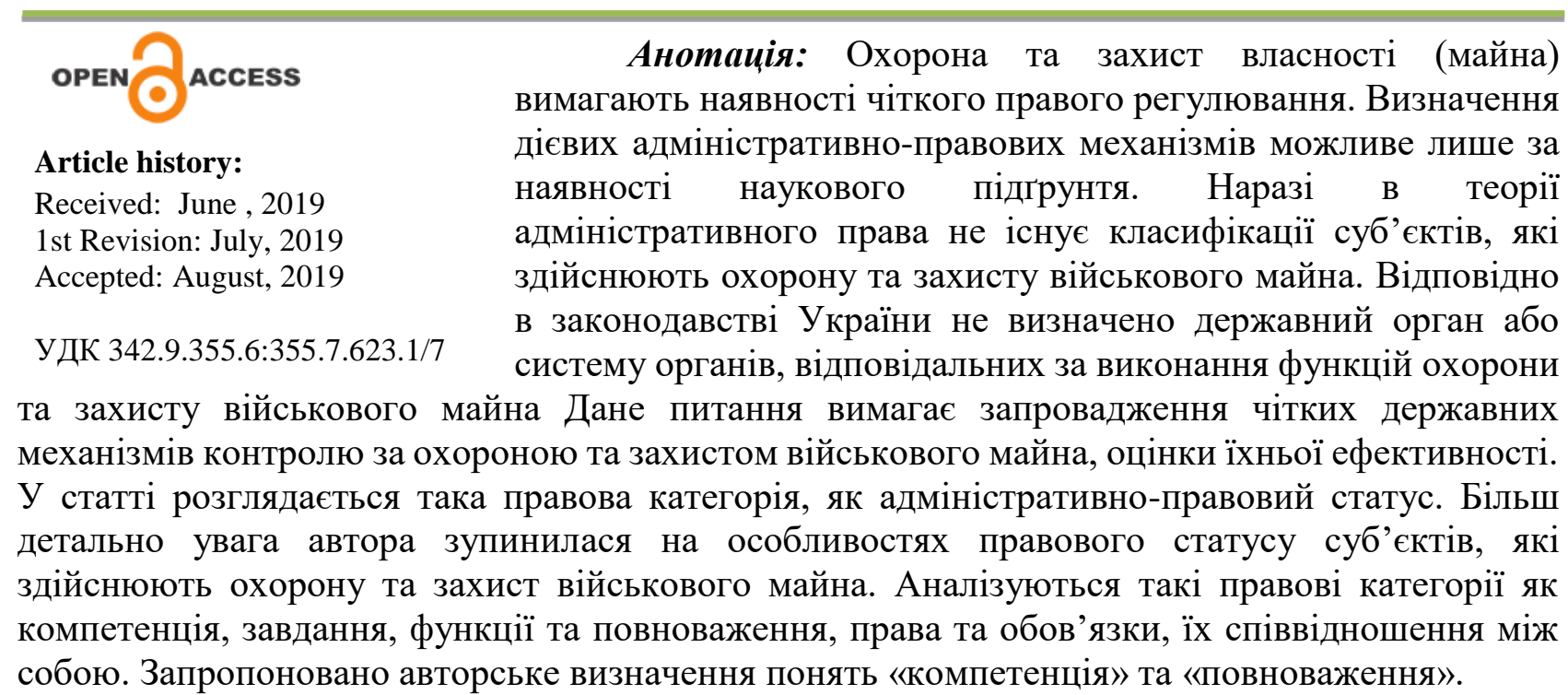

Ключові слова: адміністративно-правовий статус, компетенція, завдання та повноваження, функції, права та обов'язки, адміністративно-правова охорона, адміністративно-правовий захист, військове майно, охорона власності.

\section{1. Формулювання проблеми}

Стан адміністративно-правового регулювання охорони та захисту військового майна безпосередньо впливає на ефективність матеріальнотехнічного забезпечення Збройних Сил України, що в свою чергу відображає стан бойової готовності та можливості протистояти різним загрозам національній безпеці нашої держави.

У зв'язку з тим, що єдина система суб'єктів, які здійснюють охорону та захист військового майна відсутня, відповідно, єдиного законодавчого акту, який регулює їх діяльність також немає; різні суб'єкти можуть здійснювати охорону та захист різного військового майна. 


\section{2 Аналіз останніх досліджень та публікацій}

Проблемам адміністративно-правового статусу суб'єктів охорони та захисту майна присвячували свої праці такі вчені як А. М. Авторгов, В. В. Галунько, О. В. Дідич, Я.В. Журавель, І. В. Зозуля, В. І. Курило, А. М. Подоляка, П. В.Синицький, В. У. Хатуєв, С.В. Шестаков тощо.

У зв’язку з тим, що питання адміністративно-правового статусу суб'єктів, які здійснюють охорону та захист військового майна не були дослідженні належним чином, недосконалість правового регулювання у зазначеній сфері обумовлюють актуальність його проведення. Крім того, виявлена необхідність підвищення ефективності діяльності суб'єктів управління військовим майном щодо здійснення заходів охорони та захисту військового майна.

\section{3. Постановка завдання}

Провести аналіз законодавчих актів та відповідних підзаконних нормативно-правових актів в сфері охорони та захисту військового майна, виявити його основні недоліки та прогалини, визначити шляхи удосконалення адміністративно-правового регулювання охорони та захисту військового майна в Україні.

Мета статті полягає в тому, щоб на основі аналізу методологічних засад адміністративного права, теорії адміністративно-правової охорони права власності, чинного законодавства України та відповідних підзаконних нормативно-правових актів, узагальнення практики їх реалізації визначити сутність, особливості та зміст адміністративно-правового статусу суб'єктів, які здійснюють охорону та захист військового майна, визначити основних суб'єктів в цій сфері та проаналізувати їх завдання, функції, повноваження; формування науково-обгрунтованих пропозицій та рекомендацій щодо вдосконалення адміністративно-правового регулювання діяльності зазначених суб’єктів.

\section{2. Виклад основного матеріалу}

Діяльність щодо охорони та захисту, в тому числі, щодо надання охоронних послуг регулюється низкою нормативно-правових актів які встановлюють різні вимоги до охорони в залежності від суб'єктів охоронної діяльності та охоронюваних об'єктів. Нині в Україні наданням охоронних послуг займаються як державні органи та установи так і численні приватні суб’єкти. Найчастіше серед таких суб'єктів виділяють Поліцію охорони та приватні охоронні структури. В той же час існує низка суб'єктів охорони та захисту, в обов'язках яких $є$ функції охорони (захисту) майна, які забезпечують охорону окремого майна, в силу законодавчого закріплення відповідних завдань та функцій. Наша увага сьогодні зупиниться на суб'єктах, які здійснюють охорону та захист військового майна у з'єднаннях, військових частинах і підрозділах Збройних Сил України. 
Для з'ясування адміністративно-правового статусу суб'єктів, які здійснюють охорону та захист військового майна необхідно почати з визначення деяких правових категорій.

Під «правовим статусом» прийнято розуміти правове становище (сукупність прав і обов'язків) фізичних та юридичних осіб, державних органів.

Авер'янов О. адміністративно-правовий статус органів публічної адміністрації розуміє, як обсяг владних повноважень, а саме компетенцію, закріплену у компетенційних (або «статутних») нормативно-правових актах, що доповнюється елементами - завданнями, функціями, характером взаємозв'язків 3 іншими органами (як «по вертикалі», так і «по горизонталі»), місцем в ієрархічній структурі органів виконавчої влади, порядком вирішення установчих і кадрових питань [1, с. 30-32].

Антошин В. зазначає, що елементом адміністративно-правового статусу військового комісару є службова правосуб'єктність, яка включає службову правоздатність і службову дієздатність. Службові правоздатність і дієздатність виникають одночасно зі вступом особи у службово-правові відносини, тобто 3 часу зарахування на посаду, а припинення можливе лише щодо правосуб’єктності (при звільненні з посади) [2, с. 13-14].

В юридичній літературі, існує безліч визначень «адміністративно-правового статусу», але можна відслідкувати загальні ознаки: сукупність прав і обов'язків; їх правосуб'єктність; юридична відповідальність, завдання, функції та відповідні їм повноваження тощо.

При розгляді «адміністративно-правового статусу» поряд завжди фігурують такі поняття як «компетенція», «функції», «завдання», «повноваження», «права» i «обов'язки» та інші. Таким чином, існує необхідність приділити увагу деяким 3 цих понять.

Кожен державний орган займає певне місце в суспільній системі, вирішує певне коло справ і несе відповідальність за свою діяльність. Необхідно зазначити, що до теперішнього часу відсутній єдиний підхід до цього поняття.

Під «компетенцією» деякі науковці розуміють юридично визначені сфери і об'єкти впливу, владні повноваження як гарантована законом міра прийняття рішень.

Інші розглядають компетенцію як права i обов'язки певного суб'єкта здійснювати конкретні функції в певній сфері.

Дехто включає в поняття компетенції владні повноваження або права i обов'язки та підвідомчість (коло справ). Або розглядають головні функції управлінських органів як види впливу на об'єкти управління.

Компетенція (лат. competentia, від compete - взаємно прагну; відповідаю, підходжу) - коло повноважень якої-небудь організації, установи або особи; коло питань, в яких дана особа має певні повноваження, знання, досвід.

Заслуговує на увагу виокремлення такого поняття, як «професійна компетенція» - вміння використати знання, навички, досвід в конкретно даних умовах, досягнувши при цьому максимально позитивного результату.

На нашу думку, компетенція будь-якого суб’єкта є основною складовою його правового статусу. IIÏ можна визначити як, юридичне вираження сукупності 
завдань, управлінських функцій і відповідних наданих повноважень суб'єкту. Отже, у поняття «компетенції» закріплюються: завдання, набір управлінських функцій для конкретного суб'єкта; адекватні (відповідні їм) повноваження; склад повноважень (форми і методи) здійснення управлінських функцій; перелік керованих об'єктів.

Щодо проблеми застосування понять «функції» та «повноваження», то необхідно зазначити, що чітка наукова концепції щодо розмежування цих понять відсутня.

Серьогіна С. вважає, що терміни «повноваження» i «функція» співвідносяться між собою як поняття «засіб» і «ціль». На думку науковця, повноваження - це вид і міра можливої й необхідної поведінки органу в межах визначених функції [3, с. 68].

Часто в законодавстві України «повноваження» фактично ототожнюються 3 «правами». Так, відповідно до Закону України «Про Військову службу правопорядку у Збройних Силах України» Військова служба правопорядку у Збройних Силах України (далі - Служба правопорядку) - спеціальне правоохоронне формування у складі Збройних Сил України, призначене, серед іншого, для захисту майна Збройних Сил України від розкрадання та інших протиправних посягань, а одним з завдань Служби правопорядку є участь в охороні військових об’єктів та захист майна Збройних Сил України. Статтею 3 Закону визначаються основні завдання Служби правопорядку, статтею 7 - права військовослужбовців Служби правопорядку, статтею 8 - функції Служби правопорядку. Крім того, по тексту Закону зустрічається такі поняття як «повноваження» та «компетенція». Статтею 15 Закону зазначено, що військовослужбовець Служби правопорядку у межах своїх повноважень, наданих цим Законом та іншими законами, самостійно приймає рішення, i несе за свої протиправні дії або бездіяльність відповідальність у встановленому законом порядку. Так як переліку повноважень немає, це наочно нам демонструє, те що права та повноваження ототожнюються законотворцем у цьому Законі.

Крім того, поняття «компетенція» зустрічається лише у завданнях Служби правопорядку, як уточнююче поняття для уникнення перевищення влади Службою правопорядку. Основними завданнями Служби правопорядку є: сприяння у межах своєї компетенції органам, що здійснюють оперативнорозшукову діяльність, органам досудового розслідування та суду, органам державної влади, органам місцевого самоврядування, органам військового управління, підприємствам, установам, організаціям у виконанні покладених на них відповідно до законів обов'язків; проводити в межах компетенції спеціальну перевірку стосовно осіб, які претендують на зайняття військових посад у Збройних Силах України, пов’язаних з виконанням організаційно-розпорядчих чи адміністративно господарських обов'язків тощо [4].

Погоджуючись 3 Серьогіною С., що «повноваження» - це вид i міра можливої і необхідної поведінки, в межах функцій, спробуємо сформувати власне визначення, адаптоване під вже існуючу систему законодавства. Повноваження, на нашу думку - це визначені права, які обмежені завданнями i функціями та відповідальністю за їх перевищення. А компетенція - це певна 
сфера діяльності конкретного суб'єкта, який володіє відповідними знаннями, досвідом та наділений повноваження.

Таким чином, поняття завдання, функції, повноважень і компетенції перебувають між собою у взаємозв'язку. В завданнях відображається мета діяльності конкретного суб'єкта. Завдяки функціям реалізуються поставлені перед органом завдання. А для виконання функцій суб'єкт наділяється правами та обов'язками, які можна визначити поняттям повноваженнями. У свою чергу, компетенції - сфера діяльності конкретного суб'єкта, який володіє відповідними знаннями, досвідом та наділений повноваження

На нашу думку, головним завданням, який повинен ставити перед собою кожен суб’єкт нормотворення це недопущення включення у нормативноправовий акт формалістичних завдань, функцій, прав та інше, а також слідкувати за відповідністю завдань і функцій наданим суб’єкту повноважень.

Дослідження адміністративно-правового статусу суб'єктів, які здійснюють охорону майна в Україні є складною і об'ємною проблемою, що вимагає самостійного наукового дослідження. Як зазначає переважна більшість науковців, на сьогодні має місце не урегульованість статусів як державних, так $\mathrm{i}$ недержавних суб'єктів охоронної діяльності.

У зв’язку з вищевикладеним, в статті розглядаються лише регулювання адміністративно-правових статусів суб'єктів, які здійснюють охорону та захист військового майна.

Так, адміністративно-правовий статус суб'єктів, які здійснюють охорону та захист військового майна, їх місце та роль у державному управлінні окреслені певними правовими рамками, визначаються законами України та іншими підзаконними нормативно-правовими актами відповідно до наданих прав i покладених на них обов'язків та на підставі яких здійснюється необхідна охорона та захист.

У зв’язку з тим, що саме поняття військового майна дуже обширне, відповідно до визначень, які надані в Законі України «Про правовий режим майна у Збройних Силах України» [5] та Наказі Міністерства оборони України «Про затвердження Положення про військове (корабельне) господарство Збройних Сил України» [6] та тим що, наведені переліки військового майна (за їх видами) не $є$ вичерпним можемо бачити першу проблему, пов'язану 3 кількістю та різноманітністю військового майна.

Наступною проблемою є те, що сьогодні в теорії адміністративного права i в законодавстві не існує єдиної класифікації суб’єктів, які здійснюють охорону та захист військового майна.

Так, єдиноначальність як один із принципів будівництва i керівництва Збройними Силами України, відповідно до Закону України «Про Статут внутрішньої служби Збройних Сил України» (далі Статут), полягає в наділенні командира (начальника) всією повнотою розпорядчої влади стосовно підлеглих і покладенні на нього персональної відповідальності перед державою за всі сторони життя та діяльності військової частини, підрозділу i кожного військовослужбовця. Серед іншого командир зобов'язаний: організовувати охорону військової частини (корабля), контроль за несенням вартової та 
внутрішньої (на кораблі - чергової і вахтової) служб, не менше ніж один раз на тиждень особисто перевіряти стан їх несення; організовувати та здійснювати заходи, спрямовані на захист особового складу, озброєння, бойової та іншої техніки, матеріальних засобів від зброї масового ураження, звичайних засобів ураження.

Відповідно до пункту 147 Статуту кімната для зберігання зброї має цілодобово перебувати під охороною осіб добового наряду. п. 267 Статуту закріплено, що добовий наряд призначається для підтримання внутрішнього порядку, охорони особового складу, озброєння, боєприпасів, бойової та іншої техніки, приміщень і майна військової частини (підрозділу), контролю за станом справ у підрозділах i своєчасного вжиття заходів для запобігання правопорушенням, а також для виконання інших обов'язків внутрішньої служби. Щоденно наказом по частині призначаються черговий частини, помічник чергового частини, начальник варти, черговий парку, черговий підрозділ, а також підрозділи, від яких виділяються добовий наряд частини й особовий склад для виконання нарядів на роботи.

Таким чином, відповідно до проведеного аналізу можна зробити висновок, що відповідає за здійснення охорони (захисту) майна у військових частинах командир, деякі функції щодо охорони (захисту) мають начальник штабу та заступники командира військової частини. Щодо безпосереднього здійснення охорони (захисту) військового майна призначається добовий наряд, який міняється щоденно [7].

Як вже було здійснено аналіз та відображено в одній із робіт автора Законом України "Про оборону України", визначено, що органами військового управління є Міністерство оборони України, інші центральні органи виконавчої влади, що здійснюють керівництво військовими формуваннями, утвореними відповідно до законів України, Генеральний штаб Збройних Сил України, інші штаби, командування, управління, постійні чи тимчасово утворені органи у Збройних Силах України та інших військових формуваннях, призначені для виконання функцій з управління, в межах їх компетенції, військами (силами), 3'єднаннями, військовими частинами, військовими навчальними закладами, установами та організаціями, які належать до сфери управління центральних органів виконавчої влади, а також військові комісаріати, що забезпечують виконання законодавства з питань військового обов'язку і військової служби, мобілізаційної підготовки та мобілізації [8].

Але ні вищезазначені нормативно-правові акти, ні Закон України "Про управління об’єктами державної власності" практично не визначено завдань, функцій, повноважень суб'єктів управління майном у сфері охорони та захисту державної власності. Згідно з ч. 3 ст. 13 названого Закону, вимоги щодо організації та здійснення заходів охорони об'єктів державної власності визначають спільно відповідні суб'єкти управління та Національна поліція [9].

Так само, Закон України «Про правовий режим майна у Збройних Силах України» не містить відповідних завдань, функцій та повноважень суб'єктів управління майном у визначеній сфері. 
Не містять норм щодо компетенції органів управління стосовно охорони та захисту державної власності закони України «Про Кабінет Міністрів України», «Про центральні органи виконавчої влади», «Про місцеві державні адміністрації», Указ Президента України «Положення про Міністерство оборони України та Положення про Генеральний штаб Збройних Сил України», Постанова Кабінету Міністрів України «Про затвердження Положення про Міністерство оборони України», якими регулюються основні засади компетенції органів управління об'єктами державної власності [10, ст. 125-126].

Аналіз норм чинного законодавства свідчить про те, що законодавцем не надається належної уваги правовому регулюванню компетенції органів держави та їі посадових осіб, які здійснюють управління об'єктами права державної власності, щодо охорони та захисту об'єктів державної власності, не встановлюється відповідних обов'язків і прав державних органів, посадових осіб.

Адміністративно-правові статуси суб'єктів охорони майна об'єднує спільність завдань. Дані суб'єкти покликані забезпечувати недоторканність конкретних об'єктів, не допускати на їх територію сторонніх осіб, забезпечувати на об’єктах, що охороняються пропускний i внутрішньо об'єктний режим, попереджати і припиняти злочини і адміністративні правопорушення та інше.

Також існує схожість в формах і методах їх діяльності. Суб'єкти охорони контролюють дотримання правил, що забезпечують збереження матеріальних цінностей від розкрадань, псування, втрати, знищення, шляхом спостереження за виконанням вимог пропускного та внутрішнього режиму, шляхом контролю за законністю вивозу (виносу) матеріальних цінностей з території об'єкта, а також шляхом обстеження приміщень і території об’єкта.

Діяльність названих суб'єктів має спеціальну спрямованість. Тому, на нашу думку правові акти, які закріплюють їх компетенцію, мають визначати їх завдання, функції та повноваження тільки в сфері охорони майна. Здійснюючи функцію охорони майна, ці формування не мають бути наділені правом розпорядження майном, довіреним їм для охорони. Їх призначення полягає в тому, щоб охороняти (захищати) об'єкти та майно, що в них знаходиться від протиправних посягань.

Отже, на відміну від органів (осіб), які охороняють майно військових частин, поряд 3 здійсненням інших функцій, напевне більш ефективно це зробили б спеціальні підрозділи, які мають своїм основним завданням безпосередню охорону майна та відповідні повноваження для цього, володіють певними вміннями та навичками.

Наказ Міністерства оборони України «Про затвердження Інструкції 3 організації охорони та захисту військового майна, яке знаходиться на території державних підприємств, що належать до сфери управління Міністерства оборони України, силами Військової служби правопорядку у Збройних Силах України» (далі Наказ) визначає об’єкт охорони - військове майно, яке знаходиться на території державних підприємств, що належить до сфери управління Міністерства оборони України, а також суб'єкта охорони та захисту Військова служба правопорядку у Збройних Силах України. 
Даним Наказом визначено, що для охорони та захисту військового майна, яке знаходиться на території державних підприємств, за рішенням Міністра оборони України залучаються чергові зміни охорони від підрозділу Служби правопорядку, забезпечені спеціальними засобами та відряджені для виконання завдання щодо охорони та захисту військового майна [11].

Як вже неодноразово зазначалося автором та звертається увага колективу авторів підручника Військове право, наразі пріоритетним національним інтересом України у сфері зовнішньополітичної діяльності визначено відновлення та подальше поглиблення відносин стратегічного партнерства України з Організацією Північноатлантичного договору (НАТО) щодо набуття членства в Організації Північноатлантичного договору. На підтримку цього безперервного процесу $є$ Річні національні програми, які відображають цілі національної реформи в України і забезпечують Річні плани іiі реалізації [12, ст. 71-90]

Так, Річною національною програмою під егідою Комісії Україна - НАТО на 2017 рік було заплановано реформування системи логістики у секторі безпеки i оборони України. Було виділено необхідність здійснення кардинальної реформи системи матеріально-технічного забезпечення у секторі безпеки i оборони України підтверджується досвідом проведення антитерористичної операції в окремих районах Донецької та Луганської областей, зазначається в концепції. Головною метою реформи визначили створення єдиної ефективної системи логістики і постачання сил оборони як у мирний час, так і в особливий період для максимально оперативного і належного задоволення потреб сил оборони 3 централізованою закупівлею матеріально-технічних засобів 3 урахуванням керівних документів НАТО.

Цілями, які поставила Концепція, є: запровадження уніфікованої системи логістичного забезпечення Збройних Сил України, інших військових формувань та правоохоронних органів, а також публічних закупівель для складових сектору безпеки і оборони України; здійснити перегляд та оптимізацію показників військових, оперативних, стратегічних запасів озброєння та військової техніки, військово-технічного майна та матеріально-технічних засобів, вжити заходів до їх відновлення (модернізації). Крім того, це створення єдиного реєстру озброєння і військової техніки, військово-технічного майна, ракет і боєприпасів та матеріально-технічних засобів, а також автоматизація процесів їх обліку, закупівель і постачання [13].

Річною національною програмою під егідою Комісії Україна - НАТО на 2018 рік було заплановано здійснити технічне оснащення відповідних підрозділів для ефективної реалізації функцій із стратегічних комунікацій у Міністерстві оборони України та Збройних Силах України. Реформування систем матеріально-технічного та медичного забезпечення (логістики) Збройних Сил України: удосконалити процеси логістичного забезпечення сил оборони відповідно до стандартів НАТО; сформувати на базі Тилу і Озброєння Збройних Сил України Командування Сил логістики; здійснити відновлення (модернізацію) військових, оперативних, стратегічних запасів озброєння та військової техніки, військово-технічного майна і матеріально-технічних засобів. 
Продовжити за підтримки Трастового фонду НАТО з реформування систем логістики та стандартизації Збройних Сил України реалізацію пілотних проектів щодо: створення інформаційної системи управління стандартизацією у сфері оборони; впровадження автоматизованих систем управління обліком і рухом військового майна на основі стандартів НАТО; досягнення технічної сумісності озброєння, військової та спеціальної техніки; продовжити співпрацю України 3 державами - членами НАТО у рамках роботи комісій військово-технічного співробітництва [14].

Наразі Уряд схвалив проект Указу Президента «Про затвердження Річної національної програми під егідою Комісії Україна - НАТО на 2019 рік»

Таким чином, на шляху України до зближення з Північноатлантичним альянсом, помічаємо позитивні зрушення майже у всіх сферах. Військове майно тому не виключення.

Автором вже зверталася увага, на те що після анексії Автономної республіки Крим, Міністерство юстиції готуючи заяву до суду щодо компенсації за майно, яке там залишилося, звернулося до Міністерства оборони України, 3 проханням надати переліки майна, яке знаходилися у військових частинах півострову. В ході інвентаризації виникли проблеми пов'язані з відсутністю документації, належних реєстрів, баз даних та інших обліків майна та нерухомості. В результаті, інвентаризація окремих об'єктів здійснювалася комісійно, шляхом опису по факту наявності майна, а іноді “зі слів посадових осіб".

Критерії та рекомендації НАТО, з одного боку, не прості, з іншого-дуже ефективні для нашої держави. Реформування сектору безпеки та оборони, переведення Збройних Сил України на стандарти НАТО це першочергові завдання, в умовах що склалися, для зміцнення демократії, незалежності та територіальної цілісності нашої держави. Такі завдання, як здійснення перегляду та оптимізації показників військових, оперативних, стратегічних запасів озброєння та військової техніки, військово-технічного майна та матеріальнотехнічних засобів; їх відновлення (модернізація); створення єдиного реєстру озброєння і військової техніки, військово-технічного майна, ракет і боєприпасів та матеріально-технічних засобів; автоматизація процесів їх обліку, закупівель і постачання та інші, призведуть до налагодження та спрощення обліку військового майна, та допоможуть уникнути ситуацій таких як 3 майном Автономної Республіки Крим.

\section{3. Висновки і перспективи подальших досліджень}

Зроблено висновок про те, що «адміністративно-правовий статус» $\epsilon$ складною категорією, у зв'язку з тим, що законодавство не визначає систему складових елементів, в науці адміністративного права щодо визначення зазначеного поняття до цього часу тривають чисельні дискусії. Через це, часто не приділяється достатня увага правильному визначенню та розмежуванню таких категорій, як функції, завдання, повноваження, права, обов'язки та інше. У законодавстві України поняття «права» та «повноваження» часто 
ототожнюються, «функції» та «завдання» не мають чіткого розмежування, іноді зустрічаються формалістичні завдання або ті, які не відповідають наданим суб’єкту повноваженням

На основі вищевикладеного пропонується внести зміни до законодавства України щодо охорони (захисту) військового майна; прописувати лише ті завдання, функції суб’єктам, які необхідні для забезпечення ефективної, цілеспрямованої і планомірної роботи та надавати відповідні повноваження.

Таким чином, для підвищення ефективності діяльності суб'єктів охорони та захисту військового майна, необхідно визначити спеціальний орган, основними завданням якого буде охорона та захист військового майна та надані відповідні повноваження. Крім того, на нашу думку, необхідно впровадження класифікації суб’єктів, які здійснюють охорону та захист військового майна.

\title{
Author details (in Russian)
}

\section{Проблемные вопросы правового регулирования деятельности субъектов, осуществляющих охрану и защиту военного имущества}

\author{
Оксана Мельник *, Вячеслав Тенешев ** \\ * Военный институт Киевского национального университета имени Тараса Шевченко, \\ ул. Ломоносова, 81, г. Киев, 03022, Украина, \\ e-mail: o_mel_nik@ukr.net, \\ адъюнкт научно-организационного отделения.
}

** Тернопольский национальный экономический университет, ул. Львовская, 11 г. Тернополь 46009, Украина, e-mail: krakatuk14@gmail.com, преподаватель кафедры международного права, международных отночений и дипломатии.

Аннотация: Охрана и защита собственности (имущества) требуют наличия четкого правового регулирования. Определение действенных административно-правовых механизмов возможно лишь при наличии научной базы. Сейчас в теории административного права не существует классификации субъектов, осуществляющих охрану и защиты военного имущества. Соответственно в законодательстве Украины не определен государственный орган или систему органов, ответственных за выполнение функций охраны и защиты военного имущества Данный вопрос требует введения четких государственных механизмов контроля за охраной и защитой военного имущества, оценки их эффективности.

В статье рассматривается такая правовая категория, как административно-правовой статус. Более подробно внимание автора остановилась на особенностях правового статуса субъектов, осуществляющих охрану и защиту военного имущества. Анализируются такие правовые категории как компетенция, задачи, функции и полномочия, права и обязанности, их соотношение между собой. Предложено авторское определение понятий «компетенция» и «полномочия».

Ключевые слова: административно-правовой статус, компетенция, задачи и полномочия, функции, права и обязанности, административно-правовая охрана, административно-правовая защита, военное имущество, охрана собственности. 
Author details (in English)

\title{
Problematic issues of legal regulation of the activities of entities engaged in the protection and defense of military property
}

\author{
Oksana Melnyk *, Vyacheslav Teneshev ** \\ * Military Institute of Taras Shevchenko National University of Kyiv, \\ 81, Lomonosov Str., Kyiv, 03022, Ukraine, \\ e-mail:o_mel_nik@ukr.net, \\ post-graduate student. \\ ** Ternopil National Economic University, \\ 11, Lviv st., Ternopil 46009, Ukraine, \\ e-mail:krakatuk14@gmail.com, \\ lecturer in the Department of International Law, International Relations and Diplomacy.
}

Abstract: Protection and defense of property require the existence of clear legal regulation. The definition of effective administrative and legal mechanisms is possible only in the presence of a scientific basis. Currently, in the theory of administrative law, there are no classifications of entities that carry out the protection and defense of military property. Accordingly, the legislation of Ukraine does not specify a state body or system of bodies responsible for performing the functions of protection and defense of military property. This issue requires the introduction of clear state mechanisms for monitoring the protection and defense of military property, assessing their effectiveness.

The article deals with a legal category such as administrative and legal status. In more detail, the author drew attention to the peculiarities of the legal status of the subjects who carry out the protection and defense of military property. The following legal categories are analyzed: competence, tasks, functions and powers, rights and obligations, and their correlation with each other. Author's definition of the concepts of "competence" and "authority" is proposed.

Keywords: administrative-legal status, competence, tasks and powers, functions, rights and obligations, administrative-legal protection, administrative-legal protection, military property, property protection.

\section{Використана література}

1. Авер'янов В. Організація виконавчої влади: необхідність усунення внутрішніх суперечностей. Право Украӥни. 2009. № 5. С. 30-35.

2. Антошин В. Адміністративно-правовий статус військового комісара : автореф. дис. ... канд. юр. наук : спец. 12.00.07 «Адміністративне право і процес; фінансове право; інформаційне право». В. М. Антошин. Київ, 2013. 21 с.

3. Серьогіна С. Президент України в механізмі формування української державності. Конституційно-правові засади становлення української державності [за ред. В. Я. Тація та Ю. М. Тодики]. Харків : Право, 2003. 328 с.

4. Про Військову службу правопорядку у Збройних Силах України: Закон України від 07.03.2002. № 3099-III. URL: https://zakon.rada.gov.ua/laws/show/3099-14

5. Про правовий режим майна у Збройних Силах України: Закон України від 21.09.1999 p. №1075-XIV. URL: https://zakon.rada.gov.ua/laws/show/1075-14.

6. Положення про військове (корабельне) господарство Збройних Сил України затверджене Наказом Міністра оборони України від 16 липня 1997 року №300. URL: https://zakon.rada.gov.ua/laws/show/z0615-97 
7. Про оборону України: Закон України від 06.12.1991 p. № 1932-XII. URL: https://zakon.rada.gov.ua/laws/show/1932-12

8. Про Статут внутрішньої служби Збройних Сил України: Закон України від 24.03.1999 № 548-XIV. URL: https://zakon.rada.gov.ua/laws/show/548-14?find=1\&text=\% $\mathrm{EE} \% \mathrm{~F} 5 \% \mathrm{EE} \% \mathrm{~F} 0 \% \mathrm{EE} \% \mathrm{ED \# w} 17$

9. Про управління об’єктами державної власності: Закон України від 21.09.2006 № 185-V. URL: https://zakon.rada.gov.ua/laws/show/185-16

10. Мельник О. Правове регулювання управління військовим майном як складова адміністративно-правової охорони та захисту такого майна. Право і суспільство. 2018. № 5 частина 2. С. 122-127.

11. Інструкція 3 організації охорони та захисту військового майна, яке знаходиться на території державних підприємств, що належать до сфери управління Міністерства оборони України, силами Військової служби правопорядку у Збройних Силах України, затвержена Наказом Міністерства оборони України від 30.03.2016 №172. URL: https://zakon.rada.gov.ua/laws/show/ru/z0630-16

12. Військове право: підручник / за ред. І.М. Коропатніка, І.М.Шопіної. Київ: Алерта, 2019. 648 с.

13. Річна національна програма під егідою Комісії Україна - НАТО на 2017 рік, затверджена Указом Президента України від 8 квітня 2017 року № 103/2017. URL: https://zakon.rada.gov.ua/laws/show/103/2017

14. Річна національна програма під егідою Комісії Україна - НАТО на 2018 рік, затверджена Указом Президента України від 28.03.2018 № 89/2018. URL: https://zakon.rada.gov.ua/ laws/show/89/2018

\section{References}

1. Averianov V. (2009.) Orhanizatsiya vykonavchoyi vlady: neobkhidnist' usunennya vnutrishnikh superechnostey. [Organization of executive power: the need to eliminate internal contradictions]. Pravo Ukrainy - Law of Ukraine, 5, 30-35. [in Ukraine].

2. Antoshyn V. (2013). Administratyvno-pravovyy status viys'kovoho komisara [Administrativelegal status of the military commissar]. Extended abstract of candidate's of jurisprudence. Kiev: Kyyiv [in Ukraine].

3. Serohina S. Prezydent Ukrayiny v mekhanizmi formuvannya ukrayins'koyi derzhavnosti [President of Ukraine in the mechanism of formation of Ukrainian statehood]. Konstytutsiinopravovi zasady stanovlennia ukrainskoi derzhavnosti [za red. V. YA. Tatsiya ta YU. M. Todyky]. Pravo - Constitutional and legal principles of the formation of Ukrainian statehood edited by V. Tatiya and Y. Todyky]. Right. 328 [in Ukraine].

4. Zakon Ukrayiny «Pro Viys'kovu sluzhbu pravoporyadku u Zbroynykh Sylakh Ukrayiny» 07.03.2002. № 3099-III [Law of Ukraine About the Military Service of the Law Enforcement in the Armed Forces of Ukraine, March 7, 2002. 3099-III]. Retrieved from https://zakon.rada.gov.ua/ laws/show/3099-14. [in Ukraine]

5. Zakon Ukrainy «Pro pravovyy rezhym mayna u Zbroynykh Sylakh Ukrayiny» [The Law of Ukraine «On the legal regime of property in the Armed Forces of Ukraine» 21.09.1999, 1075XIV]. Retrieved from https://zakon.rada.gov.ua/laws/show/1075-14. [in Ukraine].

6. Nakaz Ministra oborony Ukrayiny «Polozhennya pro viys'kove (korabel'ne) hospodarstvo Zbroynykh Syl Ukrayiny zatverdzhene» [The Order of the Minister of Defense of Ukraine «Regulation on the military (shipbuilding) economy of the Armed Forces of Ukraine» of 16 July 1997, 300]. (Ukr.). Retrieved from https://zakon.rada.gov.ua/laws/show/z0615-97.

7. Zakon Ukrainy «Pro oboronu Ukrayiny» [The Law of Ukraine «On the Defense of Ukraine» of December 6, 1991, 1932-XII]. (Ukr.). Retrieved from https://zakon.rada.gov.ua/ laws/show/1932-12. [in Ukraine]

8. Zakon Ukrayiny «Pro Statut vnutrishn'oyi sluzhby Zbroynykh Syl Ukrayiny» 24.03.1999 № 548XIV. [Law of Ukraine On the Statute of the Internal Service of the Armed Forces of Ukraine 
from 24.03.1999, 548-XIV]. (Ukr.). Retrieved from https://zakon.rada.gov.ua/laws/show/54814 ?find $=1 \&$ text $=\% \mathrm{EE} \% \mathrm{~F} 5 \% \mathrm{EE} \% \mathrm{~F} 0 \% \mathrm{EE} \% \mathrm{ED} \# \mathrm{w} 17$ [in Ukraine]

9. Zakon Ukrayiny «Pro upravlinnya ob"yektamy derzhavnoyi vlasnosti» 21.09.2006 № 185-V [Law of Ukraine About management of objects of state property dated September 21, 2006, 185-V]. (Ukr.). Retrieved from https://zakon.rada.gov.ua/laws/show/1859-16 [in Ukraine]

10. Melnyk O. (2018). Pravove rehulyuvannya upravlinnya viys'kovym maynom yak skladova administratyvno-pravovoyi okhorony ta zakhystu takoho mayna. [Legal regulation of the management of military property as a component of administrative and legal defense and protection of such property]. Pravo i suspil'stvo - Law and Society, 572. 122-127. (Ukr.).

11. Nakaz Ministerstva oborony Ukrayiny «Instruktsiya $\mathrm{z}$ orhanizatsiyi okhorony ta zakhystu viys'kovoho mayna, yake znakhodyt'sya na terytoriyi derzhavnykh pidpryyemstv, shcho nalezhat' do sfery upravlinnya Ministerstva oborony Ukrayiny, sylamy Viys'kovoyi sluzhby pravoporyadku u Zbroynykh Sylakh Ukrayiny», 30.03.2016 №172 [Order of the Ministry of Defense of Ukraine An instruction on the organization of protection and defense of military property located on the territory of state enterprises belonging to the management of the Ministry of Defense of Ukraine, by the Military Service of Law and Order in the Armed Forces of Ukraine, March 30, 2016, 172]. Retrieved from https://zakon.rada.gov.ua/ laws/show/ru/z0630-16 [in Ukraine]

12. Viys'kove pravo: pidruchnyk za red. I.M.Koropatnika, I.M.Shopinoyi. (2019). [Military Law: Textbook ed. I.M.Koropatnik, I.M.Shopina] Kyyiv: Alerta. Kyiv. 648. [in Ukraine].

13. Ukaz Prezydenta Ukrainy «Richna natsional'na prohrama pid ehidoyu Komisiyi Ukraina - NATO na 2017 rik», 8 kvitnya 2017 roku, № 103/2017. [The Decree of the President of Ukraine Annual National Program under the auspices of the Ukraine-NATO Commission for 2017, April 8, 2017, 103/2017]. Retrieved from: https://zakon.rada.gov.ua/laws/show/103/2017

14. Ukaz Prezydenta Ukrainy «Richna natsional'na prohrama pid ehidoyu Komisiyi Ukraina - NATO na 2018», 28.03.2018 № 89/2018. [The Decree of the President of Ukraine Annual National Program under the auspices of the Ukraine-NATO Commission 2018, 28.03.2018 № 89/2018]. Retrieved from https://zakon.rada.gov.ua/laws/show/89/2018 [in Ukraine] 